doi:10.1017/npt.2020.2

\title{
Bülent Batuman, New Islamist Architecture and Negotiating Nation and Islam Through Built Environment in Turkey. New York: Routledge, 2017.
}

Architecture has always been a ;political as well as an aesthetic matter when it comes to building nations, spaces, borders, and representations. It is a crucial political and aesthetic tool for establishing domination as well as constructing imagination. In New Islamist Architecture and Negotiating Nation and Islam Through Built Environment in Turkey, Bülent Batuman focuses on the relationship between architecture and politics in the Turkish context. He argues that Justice and Development Party (JDP), since 2002 when it came to power, has built its hegemony by creating an authentic Islamist urban environment, highlighting that, for JDP, building hegemony means (re)building the nation, which is also a process of urbanization (pp. 17-19). Batuman elaborates his argument in four chapters: mosque building, housing, the revolution of the urban, and the public architecture.

In "Politics of Mosque Building: Negotiating Islam and Nation," he describes mosque building as one of the architectural manifestations of the nation. Batuman demonstrates how the JDP contributed to the rise of neo-Ottomanism by both mimicking the sixteenth-century Ottoman mosque architecture, mostly the monumental ones, and using the Ottoman-Seljuk style (e.g. crown gates). This was different from the early republic during which the sixteenth-century mosques, but not the monumental mosques of this period, were replicated. Differently than the early Republican era, the modernist projects were also consciously denied by the Islamist and conservative groups, but especially by the JDP's leader, then prime minister, and now President Recep Tayyip Erdoğan. This also displays how national aesthetics depends on the taste of one man, and how Erdoğan becomes the man of taste. Aiming to become the leader of the Middle East, Erdoğan invites the presidents and prime ministers of African and Middle Eastern states to the opening ceremonies of these neo-Ottoman mosques. Hence, these ceremonies were held not only for Turkish people, but also for the Islamic community in general. With regard to this, Batuman argues that these neo-Ottoman mosques represent not Islam within the nation that refers to Islam as part of the nation, but the nation within Islam, that is, the nation as the exclusive representative of Islam (p. 67).

The mosque is not solely important for (re)building the nation, but also for (re)architecting the urban. In "Housing Subjects of New Islamism," Batuman tells how urban space is reorganized through the cases of 
Başakşehir and the North Ankara Project. In both districts, the mosque, as was the case in the Ottoman cities, lies at the center with its library, shops, and cultural center, while restaurants have become alcohol-free. Even though these housing projects have improved the former squatters' welfare to some extent, Batuman argues that they have also reproduced social inequalities and socio-spatial segregation. For instance, Başakşehir is divided into four parts and the upper classes mainly inhabit in the fourth part in isolation, engaging in religious and consumption practices away from the lower classes.

In the fourth chapter, following Lefebvre's concept of urban revolution, Batuman moves from the urban revolution of the new Islamist government to the revolution of the urban. He demonstrates how the transformations that paved the way for destruction of green spaces as well as historical areas and their memories in İstanbul and Ankara under the new Islamist regime have produced protests, the most important of which was the Gezi Park protests of 2013. Batuman describes the movement as the revolution of the urban that brought a new style of resistance, camping and/or occupying the public sphere, referring to it as the manifestation of the peoples' right to the city.

In the final chapter, "Building the National: The Public Architecture of Millet," Batuman goes back to the discussion of public buildings constructed during the JDP period such as schools, courthouses, and most importantly the JDP headquarters and the Presidential Compound in Ankara. He draws the readers' attention to the dolomite facades with crown gates of these monumental buildings (p. 223-230). Both JDP's headquarters and the Presidential Compound demonstrate how the new Islamist government was inspired by the architectural styles of the Turkic states such as Kazakhstan, Azerbaijan, and Turkmenistan as well as Western classicism and the Ottoman-Seljuk style. Batuman argues that in combining Turkish Islam with Western classicism, these buildings represent a post-national classic style. By showing the humorous reactions to the Presidential Compound which, for Batuman, were inspired by the Gezi Park protests, the author also underlines the failure of JDP's project of (re)building the nation.

Batuman's book starts where Sibel Bozdoğan's work on the built environment in the early Republican Turkey ends. ${ }^{1}$ He makes a crucial contribution to the literature on history of architecture in Turkey by demonstrating the transformation of built environment in the post-Kemalist era. Nonetheless, there are several aspects that, I think, should be emphasized. First,

1 Bozdoğan, S. Modernism and Nation Building: Turkish Architectural Culture in the Early Republic. Seattle and London: University of Washington Press, 2001. 
Batuman argues that public architecture is an important ideological tool for the Islamists (p. 262). For political actors from different ideological traditions, architecture has always been a crucial political and aesthetic tool for establishing domination, legitimization of that domination, building a nation, its history, memory, etc. Hence, struggles between competing ideologies take architectural forms as well, and the Islamist government in Turkey follows the same path to change the Kemalist imagination of the nation. How the book discloses the recent architectural transformation in Turkey in relation to political, social, and economic as well as cultural changes in Turkey is very crucial; however, we should remember that public architecture has not become an important ideological tool only for the JDP government. Hence, theoretically, the fact that JDP changed public architecture is not new, but its way to change the imagination makes the case idiosyncratic. And this is what makes Batuman's work valuable.

Second, the structure of the book is confusing to the reader. First, the reader begins with mosque building and its architectural style. Then, s/he continues with a housing chapter where s/he expects to read discussions on architectural style, but instead reads about the practices of the inhabitants. Arriving at the following chapter, the reader finds her/himself reading about the Gezi Park protests, and then s/he goes back to discussions of JDP's public architecture program. This structure book leads one to question why the mosque-building chapter is separated from the chapter on public architecture; and if the study is on JDP's idiosyncratic architecture, why we are reading a chapter on the Gezi Park protests? To avoid such confusions, the book could be divided into two main chapters. For example, it could start with a chapter on public architecture that includes mosques, schools, courthouses, and the Presidential Compound building. Then it could continue with "private architecture" that analyzes JDP's housing projects and the impact of the JDP's public architectural style on interior designs, on house decorations. The influence of the public on the private is also a crucial point that is neglected in the book. Third, Batuman disregards the relationship between JDP's idiosyncratic architecture and neoliberalism. As a result, several important questions raised by the book remain unanswered. For instance, even though Batuman draws the readers' attention to how mosques have shops and libraries, and to how every district has its grand shopping center, he does not explain why. Thinking these questions through the relationship between JDP's politics of space and neoliberalism could offer important insights into the influence of neoliberalism on Islamist architecture. In other words, looking at the relationship between architecture and neoliberalism in JDP's case could demonstrate how global political as well as economic changes affect local (architectural) cultures. This may be the subject of a future research. 
Highlighting how architecture is a political and aesthetic tool for imagination, Batuman's book on Islamist architecture is a valuable contribution as it shows how the built environment in Turkey has transformed in the early twenty-first century. Focusing on the new architectural landscape of, mainly, İstanbul and Ankara, the study contributes to the scholarship on urban renewal projects, gentrification, and the right to the public sphere. In this regard, New Islamist Architecture and Negotiating Nation and Islam Through Built Environment in Turkey is a must read book for scholars as well as students who are interested in urban studies, architecture, and sociology of architecture, along with sociology of aesthetics, but in general for people who are eager to understand the current political and aesthetic transformation of Turkey. Last but not least, following Batuman's analysis, to study the influence of JDP's public architecture on individual tastes is a future challenge for interested scholars and/or students.

Gözde Cöbek

Koç University, Turkey 